\title{
Los santuarios de la patria La representación histórica de la Independencia en los museos chilenos
}

\author{
The sanctuaries of the homeland. \\ The historical representation of Independence in Chilean museums \\ Cristian UrzÚa Aburto \\ $\triangle$ cristianeduardourzua@gmail.com \\ [orcid.org/0000-0002-5469-0583]
}

\section{RESUMEN}

El museo histórico comenzó a bosquejarse en Chile con exhibiciones esporádicas durante todo el siglo XIX, pero tomó forma definitiva con la inauguración del Museo Histórico Nacional en 1911, surgiendo posteriormente distintos museos que hasta el día de hoy reproducen un imaginario épico y heroico. En este contexto, el presente artículo busca identificar, caracterizar e interpretar las exhibiciones actuales vinculadas a la Independencia en Chile (1810-1826) en cinco museos históricos (Museo Histórico Nacional, Museo Histórico y Militar, Museo del Carmen de Maipú, Museo Marítimo Nacional y Museo Regional de Rancagua), explorando su origen, trayectoria y proyecciones. Se establece que estos museos, pese a sus reformulaciones, tienen un relato común que los erige como santuarios seculares donde se les rinde culto a la patria y a sus próceres. Se indagan además miradas historiográficas y exposiciones museales críticas que tensionan el relato oficial y permiten una reflexión que complejiza el proceso independentista.

Palabras Clave: museos, museología, patrimonio histórico, Independencia de Chile, representaciones sociales.

\section{ABSTRACT}

The historical museum began to be sketched in Chile with sporadic exhibitions troughout the nineteenth century, but it took definitive form with the inaguration of the Museo Histórico nacional en 1911, subsequently emerging different museums that to this 
day reproduce an epic and heroic imaginary. In this context, this article seeks to identify, characterize and interpret the current exhibitions linked to Independence in Chile (18101826) in five historical museums (Museo Histórico Nacional, Museo Histórico y Militar, Museo del Carmen de Maipú, Museo Marítimo Nacional and Museo Regional de Rancagua), exploring its origin, trajectory and projections. It is established that these museums, despite the reformulations in their scripts they have a common narrative that erects them as secular shrines where the fatherland and this heroes are workshipped. Historiographical views and critical museum exhibitions are also investigated, that stress the oficial narrative and allow a reflection that complicate the independence process.

Key Words: museums, museology, historical heritage, Independence of Chile, social representations.

\section{INTRODUCCIÓN}

"En Rancagua dio trémula nota el clarín de la muerte al sonar y fue un riego la sangre patriota para el árbol de la libertad. Ave Fénix, que nunca perece revestida de un nimbo triunfal, ¡Oh Rancagua! Tu gloria florece en un loco heroísmo inmortal (...)"1

La institución museo, como parte de un fenómeno moderno en América Latina vinculado a la construcción del Estado-nación, se erige como uno de los dispositivos fundamentales en la conformación de un imaginario patrio. Es en el museo histórico, en particular, como un santuario secular, donde se exaltan a los héroes y a sus reliquias, buscando establecer un modelo de identidad nacional afín con los intereses de los grupos dominantes. Gran parte así de la construcción del relato museal se encuentra centrado en los procesos de Independencia impulsados en las colonias hispanoamericanas a inicios del siglo XIX, punto axial de una narrativa oficial a través de la cual el Estado interpreta su pasado (el mundo hispano-colonial) y su porvenir (la república por construir). El surgimiento del nacionalismo, en efecto, es un fenómeno global dirigido por una elite que "inventa" símbolos, tradiciones y liturgias, una suma de distintos dispositivos simbólicos que busca conformar una identidad nacional (Hobsbawm \& Ranger, 2002) y donde el museo es una herramienta política clave en la construcción del imaginario nacionalista (Anderson, 2013).

$1 \quad$ Extracto del "Himno a Rancagua" del poeta Oscar Castro, leyenda inscrita en la sala "Rancagua en la Independencia" del Museo Regional de Rancagua. 
La conformación del Estado republicano en Chile demandó la instalación de un imaginario con el que los nuevos ciudadanos pudieran identificarse, así como de un relato fundador que condujera al país por la senda de la civilización y el progreso. Para ese fin, desde el siglo XIX se erigieron monumentos públicos para conmemorar la Independencia, configurando poco a poco un panteón de próceres y una serie de acontecimientos históricos memorables (Urzúa, 2019; Voionmaa, 2005). El origen del museo en Chile se vincula a este propósito de recopilación y exhibición de colecciones, pues durante el periodo decimonónico actúa como difusor del proyecto estatal de construcción nacional (Schell, 2003) donde las exposiciones artísticas e históricas forman parte del proceso de autoafirmación del Estado-nación y que además de su dimensión política, incluye territorio, población, recursos naturales, historia y costumbres (Urizar, 2012).

Las colecciones fundacionales de los museos, junto a los monumentos históricos y bienes intangibles que son considerados públicamente valiosos son “(..) aquellos que representan la visión de mundo de una pequeña fracción de la sociedad. Con ello se establece una clara dicotomía entre una «cultura oficial», propia de los grupos dominantes y asociada a un espíritu moderno, y «una cultura popular», representativa de los otros y lo tradicional” (Seguel, 1999, p. 8). Se conforma así una cultura oficial que está íntimamente ligada a lo militar y al periodo histórico de la Independencia, como es el caso del Museo Histórico Nacional, cuya historia está fundamentalmente militarizada (Gómez \& Infante, 2012). Esta historia oficial, elitista y castrense impondría, en términos de Smith (2006), un discurso autorizado que "ignora una diversidad de experiencias culturales y sociales subnacionales" (p. 30). Desde esta perspectiva los patriotas en el museo aparecen como un grupo homogéneo y unificado, ignorando así miradas subalternas, provinciales o antagónicas.

En Chile, los museos históricos que exhiben e interpretan la Independencia no escapan a estos postulados, mostrando un relato que resalta la idea de gesta nacional y el perfil heroico de sus próceres. Pese a los avances conceptuales, teóricos y empíricos en las disciplinas vinculadas al patrimonio, la museología y la historiografía, el relato fundacional se ha mantenido casi incólume y sin cuestionamientos debido a consensos institucionales e intereses políticos que determinan lo que se debe contar y exponer. Se cree por tanto necesario interpelar al museo y poner en tensión la narrativa que guía a las exposiciones sobre la Independencia y, por extensión, al museo en su conjunto. Así, este artículo indaga las problemáticas propias de la construcción de las exhibiciones museológicas vinculadas a la emancipación nacional. ¿Cómo es representada hoy la Independencia en los museos chilenos?, ¿cómo ha sido su evolución narrativa y expositiva desde inicios del siglo XIX?, ¿cómo se articula el museo con los discursos académicos e institucionales?, ¿cuáles son las miradas alternativas respecto a este proceso y su incidencia en la exposición museal?, son algunas de las interrogantes que perfila esta investigación.

Como objetivo general se busca identificar, caracterizar e interpretar las exhibiciones 
del proceso de Independencia en Chile (1810-1826)² en los museos históricos, identificando sus relatos particulares y, a la vez, la articulación de una gran narrativa que expresa en su conjunto una memoria nacional oficial. Como objetivos específicos se propone: (1) indagar en el origen y trayectoria de los museos; (2) interpretar su colección permanente vinculada a este proceso; (3) identificar el relato maestro y el juego dialógico entre las exhibiciones; (4) indagar cuestionamientos y propuestas de nuevas exhibiciones; y (5) establecer una reflexión desde la historiografía, como disciplina analítica clave para reinterpretar estos procesos y tensionar su museografía. Si bien se aborda un periodo histórico puntual, es relevante observar también las proyecciones del proceso en su conmemoración, legado y reflexiones, como instancias importantes de análisis que dan cuenta de la conformación de una memoria histórica nacional y a los museos como artilugios de su difusión. Especialmente significativas al respecto son las celebraciones del centenario y bicentenario nacional que reactivan todo el patrimonio afín a este periodo fundante de la historia nacional.

Se seleccionaron cinco museos históricos vinculados al proceso de Independencia para abordar esta problemática, estos son: Museo Histórico Nacional, Museo Histórico y Militar, Museo del Carmen de Maipú, Museo Marítimo Nacional y Museo Regional de Rancagua, los tres primeros ubicados en la Región Metropolitana de Santiago y los restantes en las regiones de Valparaíso y O’Higgins respectivamente. En torno a estos espacios se trabajó a partir de dos instancias metodológicas. La primera consistió en una exploración de campo en dichos museos (sus exposiciones permanentes) con el fin de identificar, cuantificar y cualificar los objetos y salas vinculadas a este proceso con el uso de una pauta de identificación. La segunda consta de una revisión bibliográfica y documental que busca estudiar analíticamente la trayectoria histórica del museo, sus exposiciones y objetos, como catálogos y otros textos, que constituyen una base o extensión de la exhibición misma.

Se ha trabajado en dos dimensiones de la exposición museal que reúne al conjunto particular de objetos relacionados a la Independencia y que se reflejan en la orientación de la pauta de identificación. Una tiene que ver con los Elementos Históricos vinculados a este proceso, los que se han dividido en seis categorías de análisis: Vestuario, Objeto/Mueble, Armamento, Alegórico, Pictórico y Documental, cada una fragmentada en subvariables. La otra dimensión consta de los Recursos Museográficos, constructos elaborados intencionadamente para la comprensión de la muestra como son los paneles, dioramas o montajes, entre otros.

Para el estudio de los elementos museológicos se han estructurado cinco niveles analíticos que agrupan a los objetos y que a partir de sus relaciones con su entorno -mediadas por subjetividades profanas o profesionales-conforman espacios de sentido que dan origen a la institución museal: (a) un nivel Objetual (el objeto en sí). Referente a su materialidad y significado, resquicio de un pasado, expuesto y resignificado en el museo, de acuerdo a su

Desde la Primera Junta de Gobierno (18 de septiembre de 1810) -incluyendo sus antecedentes colonialeshasta la incorporación de Chiloé a la Soberanía Nacional (22 de enero de 1826) -considerando sus proyecciones conmemorativas durante los siglos XX y XXI. 
singularidad y a las interpretaciones legadas o asignadas por los profesionales; (b) un nivel Relacional (la asociación parcial entre objetos). Corresponde a la interacción simbólica de las cosas entre sí en vitrinas o montajes, de acuerdo a su combinación, semejanza o confrontación; (c) un nivel Temático (la idea general que reúne a las piezas). Vinculado al espacio que contiene a los objetos y la temática bajo la cual son significados y ordenados en las salas de exhibición; (d) un nivel Integral (el museo en su totalidad). Concierne al museo en su conjunto, a su temática global y la misión/visión que lo orientan, a los profesionales que lo conforman y la institucionalidad a la que se subscribe; y (e) un nivel Contextual (el entorno del museo). Es el área geográfica que circunscribe al museo y su marco histórico, social, político, cultural y económico. Con esta red integral de vínculos analíticos que cruza a distintos museos es posible enriquecer el estudio de su representación histórica permitiendo así su comparación.

Los resultados de investigación se articulan en tres apartados. El primero busca establecer el origen de la musealización de la Independencia desde las primeras exposiciones hasta la actualidad, analizando los contextos y factores que han contribuido a su construcción. El segundo acápite, en base a un trabajo de catastro, organiza y analiza objetos y recursos museográficos expuestos identificando personajes y acontecimientos del periodo, que devienen en una representación canónica. Finalmente, se establecen aquellas visiones que han cuestionado la imagen independentista tradicional, primero, con propuestas historiográficas críticas que pueden contribuir a repensar la propuesta museal y, segundo, con el análisis de la exposición temporal "Hijos de la Libertad" del Museo Histórico Nacional, que rompe con el canon heroico y épico comúnmente atribuido a este acontecimiento.

\section{GÉNESIS: LA CONSTRUCCIÓN DEL MUSEO HISTÓRICO Y EL PANTEÓN DE LOS HÉROES DE LA INDEPENDENCIA}

En la naciente república de Chile una de las primeras manifestaciones de representación nacional es la construcción de una estatuaria pública, con monumentos vinculados a la gesta independentista para recordar a los próceres y sus épicas batallas. Junto con ello, la educación escolar, las exposiciones internacionales, así como la propaganda durante las guerras del siglo XIX (Guerra contra la Confederación, 1837-1839; Guerra del Pacífico, 1879-1884) contribuirían a construir parte del imaginario patrio. Por la cercanía de los acontecimientos, en aquel entonces no estaba claro quién integraría el panteón de héroes, pues la elite dirigente se encontraría todavía dividida en disputas internas que se tradujeron en una serie de guerras civiles (1851, 1859 y 1891). También, la apertura económica requería construir una identidad nacional para incentivar la cooperación e intercambio internacional mostrando al país como una nación moderna y progresista. En este contexto se comienza a construir el museo histórico, que contribuye desde la esfera de la cultura a generar un imaginario nacional. 


\section{Etapa protomuseal de la representación histórica (1813-1911)}

La primera iniciativa para levantar un museo en el país se dio en plena época independentista, cuando en julio de 1813 se establece la posibilidad de construir un Museo de Ciencias, habilitándose una sala en la Universidad de San Felipe, idea que se vio truncada con la Reconquista española en 1814. En 1822, bajo el gobierno de Bernardo O'Higgins se retoma el proyecto de establecer un Museo Nacional, pero tampoco se consolida, reanudándose más tarde con Claudio Gay en 1830, "quien inició de inmediato la gigantesca labor que dio origen a nuestro primer Museo y la más completa visión de la historia y la naturaleza de Chile hasta la fecha" (Campos \& Rodríguez, 1982, pp. 15-16). En esta etapa el acopio de objetos responde a un esfuerzo público y privado que buscaba representar a la naciente nación, estableciendo un primer criterio de selección con la adquisición de trofeos de guerra como las banderas españolas de Chacabuco y Maipú.

A mediados del siglo XIX las exposiciones -tanto nacionales como internacionalesconstituyeron instancias donde la naciente república buscó representar al país con una imagen moderna y atractiva, a la altura de las grandes potencias europeas (Norambuena, 2002-2003). Un hito relevante es la Exposición del Coloniaje del 17 de septiembre de 1873, la que incluía la narración de hazañas de algunos sobrevivientes de la época de la Independencia y la exhibición de objetos icónicos como las espadas de Bernardo O’Higgins y banderas de la Batalla de Maipú (Hernández, 2006). La muestra buscaba realzar el valor de la elite como heredera del pasado y legítima conductora del porvenir del país, instancia donde también se comenzaban a perfilar a los héroes de la gesta nacional.

Pero es el museo propiamente tal, como una institución organizada y permanente, uno de los dispositivos fundamentales para la construcción del imaginario nacional. El primer intento de creación de un museo histórico se hizo con los objetos de la muestra del coloniaje habilitando un espacio en el Castillo Hidalgo del Cerro Santa Lucía en 1874. Sin embargo, cuando fallece Benjamín Vicuña Mackenna (uno de sus precursores) el museo cerró y sus objetos se dispersaron en diferentes colecciones (Hernández, 2006). Luego, en el marco de la Guerra del Pacífico y la necesidad de fortalecer la identidad nacional, se crea el Museo de Armas Antiguas en 1879 y dos años después el Presidente Aníbal Pinto ordena la apertura de la Sala de Armas en el Museo Nacional. En 1893 se inaugura un museo militar en los Arsenales de Guerra y al año siguiente otro similar en el parque de las Fuerzas Armadas y del Arsenal. Dos años después se constituye el Museo Militar albergando la mayor parte de las colecciones militares del Ejército (Alegría \& Meirovich, 2019).

El Centenario Nacional marca un hito en la construcción de un imaginario nacionalista, pues se exaltó como nunca antes la identidad patria y las figuras de la Independencia con la construcción de monumentos y la organización de exhibiciones. Para la Exposición Histórica del Centenario de 1910 se hizo un llamado público para donar objetos históricos que serían expuestos en el Palacio Urmeneta, lográndose reunir elementos de la Independencia que hoy 


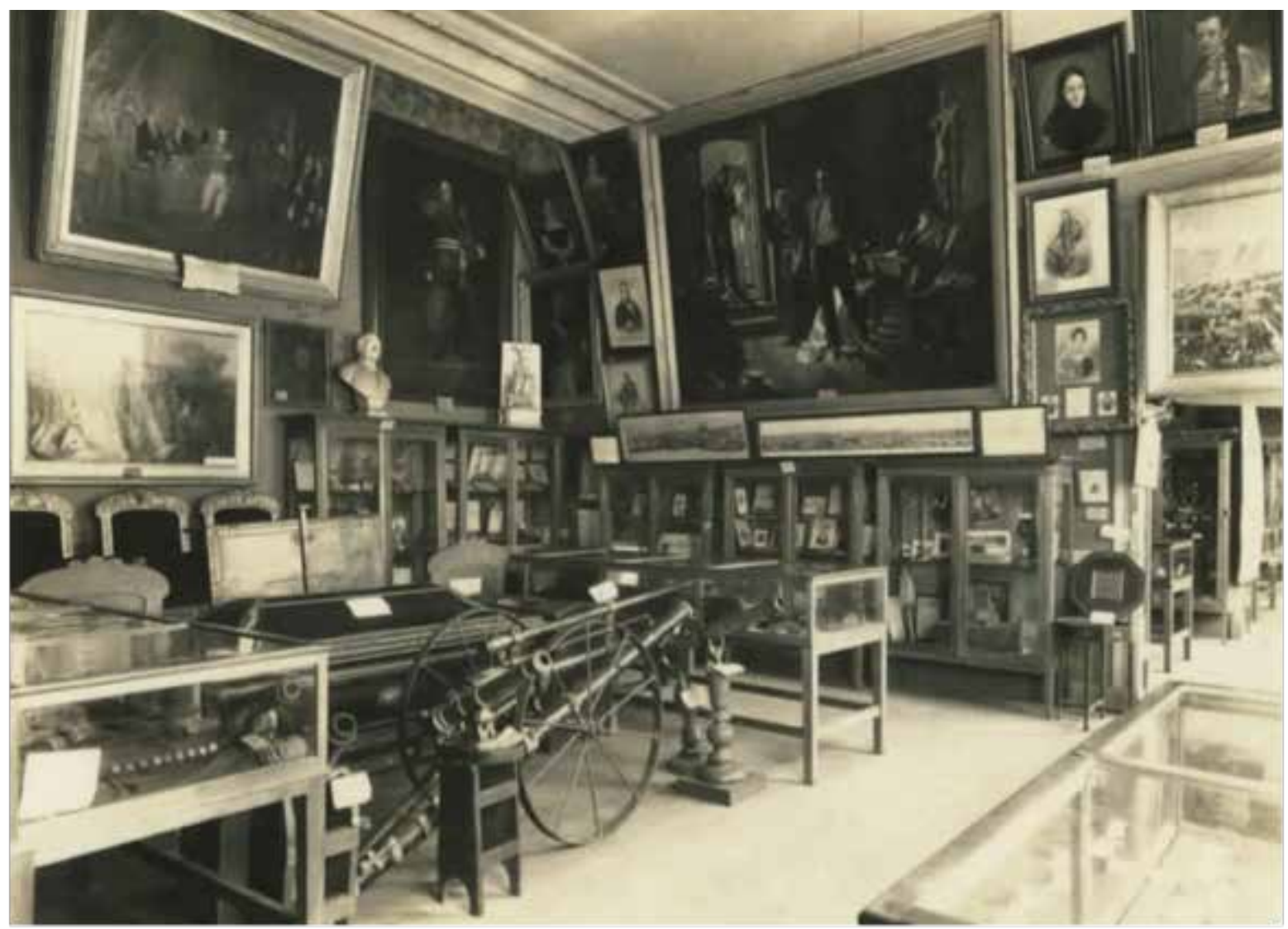

Fig. 1. Sala del Museo Histórico Nacional en el Palacio de Bellas Artes. Colección Museo Histórico Nacional, 1930.

forman parte de la colección del Museo Histórico Nacional (Fig. 1). Este hito “(...) constituye especialmente una experiencia de profundo significado identitario, una reapropiación de la memoria histórica nacional a través de una colección de objetos seleccionados y clasificados como genuinos representantes de la esencia nacional, en definitiva, monumentos de grandeza de nuestros héroes o "padres fundadores”" (Alegría \& Paz, 2007, p. 72). Así, para consolidar la memoria de la nación, dos espacios museales se construyen en este importante momento: el Museo Nacional de Bellas Artes en 1910 y el Museo Histórico Nacional en 1911.

La etapa previa a la constitución del Museo Histórico Nacional y los consiguientes museos históricos que se crearán después, la designaremos como periodo de conformación protomuseal, cuando surgen ensayos de construcción de espacios museales y de exhibiciones efímeras donde se comienzan a compilar y seleccionar aquellos objetos considerados más representativos de la historia nacional y a definir el panteón de próceres patrios. Junto con ello, la historiografía liberal (representada por Diego Barros Arana, Benjamín Vicuña Mackenna y Miguel Luis Amunátegui, entre otros) construye un relato histórico que constituye una guía sobre la cual el museo se erige, enfatizando una mirada optimista y progresista de la historia tan afín al proyecto de construcción estatal de este periodo histórico. 


\section{La consolidación del museo histórico (1911-2018)}

El Museo Histórico Nacional, creado en 1911, surge de los esfuerzos por tener un espacio de representación de la historia nacional, constituyéndose a partir de la convergencia de diversos objetos que deambularon en exposiciones temporales (Coloniaje, 1873; Santa Lucía, 1874; Centenario, 1910), proyectos museales efímeros (Museo Militar o Arsenales de Guerra), de traspasos de otros museos (Museo de Historia Natural o Museo de Bellas Artes), de salones de arte, colecciones privadas, donaciones y legados desde el siglo XIX, transitando por distintos espacios hasta su ubicación actual en el ex edificio de la Real Audiencia (Museo Histórico Nacional, 2018). Durante un largo periodo la exhibición del Museo Histórico Nacional estuvo dedicada a las figuras presidenciales y sus obras, tanto en su instalación en el edificio de calle Miraflores de la Biblioteca Nacional como en el periodo de 1982 a 1997, en su emplazamiento actual, momento cuando la trama narrativa comienza a ser cuestionada con un cambio impulsado desde 1993 por su directora Sofía Correa, estableciendo la denominada "museología de la idea" en contraposición a la "museología del objeto", inaugurándose el año 2000 nuevas salas de exhibición permanente (Alvarado et al. 2011).

Respecto a las salas actuales dedicadas a la Independencia (Tabla 1) destacan: "El Colapso del Imperio" y "La Idea de Libertad", donde la primera ilustra las batallas y héroes que participaron en el proceso, mientras que la segunda representa "(...) la idea tan propia de la época de iluminar las conciencias por medio de las ideas. Aquí se concentran las pertenencias y documentos de los próceres Carrera y O’Higgins, así como objetos con los símbolos de la República, nuevo orden político. El eje central de la sala es la bandera de la Independencia, que refleja el símbolo de la nueva nación" (Museo Histórico Nacional, 2018b, párr. 1). Por extensión la sala denominada "La Recomposición del Orden" puede considerarse como una continuación del relato independentista por cuanto una parte importante de los objetos está directamente vinculada a este acontecimiento, con especial mención de los retratos y objetos de los próceres.

El origen del Museo del Carmen de Maipú está supeditado a la construcción del Templo Votivo, mandatado por el propio Bernardo O'Higgins para cumplir con el voto realizado a la Virgen del Carmen, Patrona del Ejército de Chile, tras haber vencido en la Batalla de Maipú el 5 de abril de 1818. La promesa se concreta con la instalación de la primera piedra el 15 de noviembre de ese año, pero inaugurándose en 1892, tras una larga demora, con el nombre de Capilla de la Victoria. En 1942, en un congreso mariano encabezado por el Cardenal José María Caro, se acuerda construir un santuario monumental para reemplazar la antigua y deteriorada capilla. El 24 de octubre de 1974 se inaugura oficialmente como Templo Votivo de Maipú. En este contexto, el museo fue creado como una obra complementaria al templo inaugurándose en 1956 dependiente de la Corporación Voto Nacional O’Higgins. El museo se estructura hoy en varios espacios, donde las salas "Independencia" y "Documentos Históricos" se vinculan a la época independentista, más una parte del lugar denominado "Salones" 
Tabla 1. Museos históricos y salas vinculadas al proceso de Independencia de Chile

\begin{tabular}{|c|c|c|}
\hline MUSEO & SALAS & LOCALIZACIÓN \\
\hline Museo Histórico Nacional & $\begin{array}{l}\text { - El Colapso del Imperio } \\
\text { - La Idea de Libertad } \\
\text { - La Recomposición del Orden }\end{array}$ & $\begin{array}{c}\text { Santiago, } \\
\text { Región Metropolitana }\end{array}$ \\
\hline Museo Histórico y Militar & $\begin{array}{l}\text { - Inicio del proceso de Independencia } \\
\text { - Campañas Militares de la Patria Vieja } \\
\text { - Reconquista y Patria Nueva } \\
\text { - Gobierno de O`Higgins e incorporación de } \\
\text { Chiloé } \\
\end{array}$ & $\begin{array}{c}\text { Santiago, } \\
\text { Región Metropolitana }\end{array}$ \\
\hline $\begin{array}{l}\text { Museo del Carmen } \\
\text { de Maipú }\end{array}$ & $\begin{array}{c}\text { - Independencia } \\
\text { - Documentos Históricos } \\
\text { - Salones }\end{array}$ & $\begin{array}{c}\text { Maipú, } \\
\text { Región Metropolitana }\end{array}$ \\
\hline Museo Marítimo Nacional & $\begin{array}{c}\text { - Nuestros héroes en el Pacífico } \\
\text { - La libertad se obtuvo en el mar } \\
\text { - Formas de captura de buques en las primeras } \\
\text { décadas del siglo XIX }\end{array}$ & $\begin{array}{c}\text { Valparaíso, } \\
\text { Región de Valparaíso }\end{array}$ \\
\hline $\begin{array}{l}\text { Museo Regional } \\
\text { de Rancagua }\end{array}$ & - Rancagua en la Independencia & $\begin{array}{c}\text { Rancagua, } \\
\text { Región de O'Higgins }\end{array}$ \\
\hline
\end{tabular}

Fuente: Elaboración propia.

donde se hallan objetos concernientes a O’Higgins. El Museo del Carmen de Maipú representa ante todo la dimensión espiritual de la Independencia y la gloria de la victoria obtenida. Destacan aquí el mural "Alegoría de la Batalla de Maipú" de Fray Pedro Subercaseaux, las "reliquias de los padres de la Patria" y la sala de documentos que contiene pragmáticas del periodo colonial hasta manuscritos que se refieren a la consolidación de la república (Museo del Carmen de Maipú, 2018).

El Museo Regional de Rancagua consta de dos inmuebles, separados por la Calle del Estado: la Casa del Pilar y la Casa del Ochavo, únicos vestigios de la fundación de la ciudad en el siglo XVIII. En la primera, adquirida por la familia Flores Moreno, es donde se crea el "Museo de la Patria Vieja", en su ala sur el año 1951, adquiriéndola la Dirección de Bibliotecas Archivos y Museos (Dibam) dos años después. Pese a ello la casa estuvo abandonada y deteriorada hasta su restauración entre 1994 y 1995. La segunda casa, originalmente propiedad de la familia Rodríguez, después de pasar por varias familias es adquirida por la Municipalidad de Rancagua entre 1967 y 1968 destinándola al Museo de Rancagua, el que se traslada definitivamente a ese lugar en 1978 (Museo Regional de Rancagua, 2018). En la primera casa se realizan las exhibiciones temporales, mientras que en la segunda están las permanentes, entre ellas se encuentra la sala "Rancagua en la Independencia", donde se presentan los antecedentes y características fundamentales del proceso, separados en dos áreas: un pasillo que actúa como preámbulo que trata del origen de Rancagua, el mundo rural y los acontecimientos de la Independencia, abriendo paso a la sala principal dedicada a O'Higgins y la Batalla de Rancagua, con un gran diorama y objetos de la batalla.

El Museo Marítimo Nacional es inaugurado el año 1988 en Valparaíso, aunque el interés por su creación data de 1903, momento en que se comienza a recopilar objetos consti- 
tuyendo galerías históricas. En 1917 se decreta la creación de un Museo Naval en Valparaíso, anexo a su escuela, incrementando con el tiempo su colección de reliquias y piezas vinculadas a la historia marítima de Chile. Tras transitar por diversos espacios (Playa Ancha, Barrio El Almendral, Castillo Wulf) es inaugurado de forma definitiva por el Comandante en Jefe de la Armada José Toribio Merino el 23 de mayo de 1988 en su espacio actual, la ex Escuela Naval en el cerro Artillería (Castillo, 2007). Respecto al periodo independentista se pueden identificar tres salas denominadas: "La libertad se obtuvo en el mar", "Formas de captura de buques en las primeras décadas del siglo XIX" y una tercera denominada "Nuestros héroes en el Pacífico", que es un memorial a los héroes del mar cuya trilogía sacrosanta está compuesta por Bernardo O'Higgins, Thomas Cochrane y Arturo Prat.

En 1978 el general Augusto Pinochet ordena un estudio para la construcción de un museo dedicado al Ejército de Chile, situándolo en el Edificio Alcázar que albergó a la Escuela Militar y a la Escuela de Suboficiales, el que es inaugurado el año 1997 como Museo Histórico y Militar de Chile. Un incendio en el año 2000 destruye parte del edificio y sus colecciones, tras lo cual el alto mando impulsa el "Proyecto Clío" con el fin de investigar, restaurar y remodelar el edificio siniestrado para “(...) construir e implementar una nueva museografía ligada a aspectos educativos lúdicos, interactivos y multimediales y la re-fundación del museo" (Cari, 2012, pp. 46-47), siendo desde entonces apoyado por la Corporación de Protección del Patrimonio Histórico Militar y el departamento de Historia Militar. El museo presenta un relato cronológico del proceso en el marco amplio de la historia militar del país, desde la resistencia mapuche al Imperio Inca hasta la presencia militar en la Antártica, y que consta de las siguientes salas relacionadas a la Independencia: "Inicio del proceso de Independencia”, “Campañas Militares de la Patria Vieja”, "Reconquista y Patria Nueva” y "Gobierno de O`Higgins e incorporación de Chiloé”. Es acaso el museo que posee la mirada más integral respecto a la Independencia, exponiendo sus antecedentes y consecuencias en un relato estructurado que aborda los grandes procesos históricos en etapas cronológicas.

\section{Museografía, memoria oficial, nacionalismo y territorio}

Consignada esta breve genealogía museal, se establece el origen y desarrollo del museo y sus colecciones como un constructo histórico que obedece a factores múltiples tales como: (a) contextos territoriales socio-históricos, pues surgen en epicentros históricos vinculados a acontecimientos significativos, es decir, ubicados in situ; (b) la disponibilidad de colecciones formadas a partir del patrimonio nacional, donaciones y adquisiciones, la mayor parte objetos de tipo militar, artístico y de uso cotidiano; (c) el saber experto (historiográfico y museológico) que orienta e instala la exposición bajo determinados parámetros filosóficos, académicos y culturales; y (d) una ideología política e influencia militar que mandata la orientación de sus lineamientos y límites respecto a lo que debe mostrar y representar. Por tanto, el museo histórico se convierte en un dispositivo de poder que, de acuerdo a su 
época histórica, ha apelado a la Independencia nacional buscando legitimar al Estado, los sucesivos gobiernos y a las Fuerzas Armadas (Ejército y Marina) en pos de la construcción de una identidad nacional usando el museo como un recurso didáctico que refuerza las ideas de unidad nacional, patriotismo, ciudadanía y libertad.

Los museos históricos indicados, entre los más emblemáticos y antiguos del país, buscan representar según su misión/visión, una identidad nacional e historia objetiva y oficial del país. Son, por tanto, junto a otros dispositivos, instituciones que contribuyen a la creación de un imaginario patrio donde el protagonismo militar tiene un rol insoslayable, más aún cuando éstos están (o han estado) bajo la administración de las Fuerzas Armadas, lo cual constituye una suerte de validación de su propio rol histórico e identidad. Baste considerar que todos los museos aquí reseñados surgen o son intervenidos en el periodo de la Dictadura Militar (19731989), reformulándose su orientación una vez reconquistada la democracia. De ahí que la devoción a la patria sea un elemento ineludible para estas instituciones. Por citar un ejemplo, un panel introductorio del Museo Histórico y Militar indica que su fin es “(...) promover en la sociedad, la preservación, el conocimiento y valoración del legado histórico cultural del Ejército, contribuyendo así con el fortalecimiento de la identidad nacional". La reafirmación identitaria y el protagonismo del Ejército en estos procesos constituiría la base ideológica que guía los contenidos del museo, donde la Independencia es un eje vertebrador del relato.

El proceso de musealización de la Independencia chilena sobrepasa el propio espacio museal para insertarse en el territorio y trama urbana de la ciudad histórica que lo envuelve. El Museo del Carmen de Maipú, instalado en los campos de aquella batalla, es parte de una obra mayor que es el templo, hito monumental y simbólico de la comuna, que se desborda sobre el imaginario maipucino. Es también el caso del Museo Regional de Rancagua, cuya ciudad fue protagonista de otro hito significativo: la Batalla de Rancagua (1814), cuyo patrimonio se extiende más allá del museo mismo, en sus monumentos y sitios, donde el nombre de O'Higgins se enaltece con una estatua ecuestre en la plaza de armas de la ciudad. Santiago, centro del poder nacional, es donde se construyen los museos oficiales y más representativos de esta historia, estos son: el Museo Histórico Nacional y el Museo Histórico y Militar que concentran las colecciones más valiosas y completas vinculadas al proceso independentista, monopolizando los objetos y el relato en detrimento de las provincias. El Museo Marítimo Nacional representa por su lado la fase naval de esta historia, es por eso que se asienta en Valparaíso, asiento de la Escuela Naval, y desde donde zarpó la Escuadra Libertadora del Perú.

Se puede establecer que en las primeras exhibiciones se realiza un montaje cercano al gabinete de curiosidades, que amontona una gran cantidad de objetos sin descripción y que pone énfasis en hechos y personajes heroicos (representativa del Museo Histórico Nacional en su primera fase). Posteriormente se construyen nuevos espacios museales cuyas salas se articulan bajo una concepción estructuralista que resalta los procesos históricos desde una mirada general (evidente en los museos militares) o que conmemoran acontecimientos particulares (batallas) insertos en aquellos procesos (Museo del Carmen de Maipú y Museo 
Regional de Rancagua). Una forma distinta de exhibición es la instauración del museo de la idea, instalada después en el Museo Histórico Nacional, que exhibe a la Independencia a través de los símbolos y representaciones que sugieren los objetos. Más allá de las exposiciones permanentes, hay por último una etapa crítica que busca la deconstrucción del museo y su mediación reflexiva, presente en intervenciones y exhibiciones temporales que se describirán más tarde. Las etapas mencionadas, en todo caso, se superponen unas a otras, a manera de capas geológicas, conviviendo distintas miradas de forma simultánea en el museo derivadas de reformulaciones del guión, reordenamiento de los objetos y nuevas mediaciones educativas.

\section{EXÉGESIS: TESOROS NACIONALES Y SANTOS SECULARES}

En el museo histórico la Independencia constituye un acontecimiento insoslayable pues actúa como columna vertebral que articula todo el relato histórico nacional, interpretando su pasado y futuro. Tres aspectos son dominantes en la selección de objetos museales: éstos se vinculan irrestrictamente a temáticas militares, de combates y batallas; están sobrecargados al culto de la personalidad del prócer patriota; y una parte no menor comprende objetos conmemorativos. Naturalmente, el proceso de la Independencia fue un hecho de armas, por lo que la tipología de objetos sobre la cual se fundamenta el relato independentista es casi exclusivamente militar, de ahí su masiva presencia. Un hecho no menor que se desprende de esto es que las Fuerzas Armadas (Ejército y Armada) son las instituciones propietarias de una parte importante de estos objetos, los que han ido legando y acaparando en museos bajo su supervisión y/o influencia y por tanto bajo el peso de sus postulados ideológicos.

No obstante, hay que ser cuidadosos en la interpretación, pues como indica Castilla (2010) “(...) el discurso de los museos no debe ser confundido con los objetos o el conjunto de colecciones que lo integran. Estos objetos -dice-, como si se tratara de reliquias, pueden adquirir estado sacro por la suma de reverencias y rituales que se les dedican, pero no significan ni comunican ese estado por sí mismos, sino que requieren de la reflexión crítica que les permita acceder al intercambio de experiencias con el eventual visitante" (pp. 17-18). En el caso de estudio -se verá-, los documentos institucionales del museo, la selección y mediación misma de las colecciones, así como los recursos museográficos dispuestos para su interpretación, reafirman, por lo general, el carácter sacro de sujetos y objetos, construyendo un relato fundamentalmente nacionalista.

\section{Las reliquias de la patria}

En este apartado se realiza un análisis respecto a la selección, ordenamiento e interpretación de las colecciones museales exhibidas vinculadas a la Independencia chilena, las que se han ido conformando a partir de esfuerzos públicos y privados, a través de trayectorias históricas complejas y curadas desde distintos criterios museológicos. Pese a su 
Tabla 2. Elementos históricos de la Independencia chilena actualmente exhibidos en museos históricos

\begin{tabular}{|c|c|c|c|c|c|c|c|}
\hline CATEGORÍA & SUBCATEGORÍA & $\mathrm{MHN}^{*}$ & MHM & $\mathrm{MCM}$ & MMN & MRR & TOTAL \\
\hline \multirow{3}{*}{ VESTUARIO } & Prócer/personaje & 1 & 6 & 3 & 0 & 1 & 11 \\
\hline & Soldado/genérico & 1 & 1 & 5 & 2 & 4 & 13 \\
\hline & Total parcial 1 & 2 & 7 & 8 & 2 & 5 & 24 \\
\hline \multirow{7}{*}{ OBJETO/MUEBLE } & Prócer/personaje & 17 & 6 & 4 & 5 & 0 & 32 \\
\hline & Soldado & 2 & 1 & 0 & 0 & 0 & 3 \\
\hline & Náutico & 5 & 2 & 1 & 13 & 0 & 21 \\
\hline & Religioso & 6 & 1 & 2 & 0 & 1 & 10 \\
\hline & Cotidiano genérico & 15 & 10 & 0 & 1 & 10 & 36 \\
\hline & Mobiliario genérico & 5 & 0 & 1 & 0 & 0 & 6 \\
\hline & Total parcial 2 & 50 & 20 & 8 & 19 & 11 & 108 \\
\hline \multirow{5}{*}{ ARMAMENTO } & Sables/ espadas/ otro & 2 & 2 & 17 & 2 & 4 & 27 \\
\hline & Armas de fuego & 0 & 2 & 1 & 2 & 1 & 6 \\
\hline & Artillería & 5 & 2 & 0 & 5 & 0 & 12 \\
\hline & Proyectiles & 0 & 3 & 1 & 4 & 9 & 17 \\
\hline & Total parcial 3 & 7 & 9 & 19 & 13 & 14 & 62 \\
\hline \multirow{6}{*}{ ALEGÓRICO } & Condecoraciones & 9 & 1 & 17 & 14 & 0 & 41 \\
\hline & Conmemorativo & 2 & 0 & 3 & 2 & 0 & 7 \\
\hline & Bandera/Escudo & 2 & 0 & 3 & 2 & 0 & 7 \\
\hline & Elemento simbólico & 2 & 0 & 3 & 0 & 3 & 8 \\
\hline & Escultura & 0 & 1 & 1 & 1 & 0 & 3 \\
\hline & Total parcial 4 & 15 & 2 & 27 & 19 & 3 & 66 \\
\hline \multirow{6}{*}{ PICTÓRICO } & Prócer/personaje & 34 & 13 & 10 & 5 & 2 & 64 \\
\hline & Batalla & 5 & 0 & 1 & 0 & 1 & 7 \\
\hline & Suceso histórico & 4 & 4 & 0 & 3 & 0 & 11 \\
\hline & Religioso & 0 & 0 & 1 & 0 & 0 & 1 \\
\hline & Paisaje/costumbrista/otro & 2 & 0 & 6 & 0 & 1 & 9 \\
\hline & Total parcial 5 & 45 & 17 & 18 & 8 & 4 & 92 \\
\hline \multirow{5}{*}{ DOCUMENTAL } & Documento & 2 & 5 & 38 & 0 & 0 & 45 \\
\hline & Libro & 1 & 3 & 0 & 0 & 1 & 5 \\
\hline & Cartografía & 2 & 0 & 1 & 0 & 0 & 3 \\
\hline & Total parcial 6 & 5 & 8 & 39 & 0 & 1 & 53 \\
\hline & TOTAL GENERAL & 124 & 63 & 119 & 61 & 38 & 405 \\
\hline
\end{tabular}

*MHN: Museo Histórico Nacional; MHM: Museo Histórico y Militar; MCM: Museo del Carmen de Maipú; MMN: Museo Marítimo Nacional; MRR: Museo Regional de Rancagua.

Fuente: Elaboración propia en base a trabajo de campo en los museos entre los meses de junio, julio y agosto de 2018. 
disposición diversa, los objetos están ordenados o se enmarcan en el convencional esquema cronológico de la historia independentista, a saber: Antecedentes, Patria Vieja, Reconquista, Patria Nueva, Gobierno de O’Higgins, Formación de la Escuadra Nacional y Campaña Marítima, replicando así el esquema tradicional de narrar el periodo, tan acorde al currículo escolar, aspecto especialmente notorio en los museos militares.

Siguiendo la Tabla 2, del conjunto del vestuario destacan las prendas militares y civiles de próceres y soldados, donde predomina el uniforme militar, de tierra y mar, que consta de camisas, casacas, charreteras, bicornios, etc. Resaltan las prendas de Javiera Carrera y en segundo plano el ropaje de anónimos soldados. Más abundantes son los objetos y muebles, elementos de guerra o de uso personal (relojes, prendedores, pañuelos, elementos de aseo), junto al mobiliario de época (sillas, sillones, pianos, baúles). Los objetos náuticos, instrumentos propios de navegación (sextante, catalejo, etc.), representan la Expedición Libertadora del Perú (1820-1824), vinculados en su mayor parte, aunque no de forma exclusiva, al Museo Marítimo de Valparaíso. Un conjunto de objetos religiosos da cuenta de la base cristiano-católica de la época a través del cual el relato independentista adquiere una dimensión trascendental, y cuyas piezas corresponden a elementos de devoción privada como crucifijos e imaginería de la Virgen del Carmen, patrona y generala del ejército patriota.

El armamento es el objeto fundamental de las exhibiciones donde se distinguen armas blancas (sables, espadas, dagas), de fuego, artillería (morteros, cañones), proyectiles y municiones, pertenecientes a los próceres, oficiales y soldados. Del conjunto, las espadas y sables son el elemento icónico de la Independencia, que por su abundancia y materialidad permiten su supervivencia, por lo cual se pueden encontrar prácticamente en todas las exposiciones. Entre las decenas de sables de desconocidos soldados destacan aquellos pertenecientes a los próceres (O`Higgins, Carrera, San Martín, etc.) que, pese a ser réplicas, constituyen el objeto primordial, el más valorado del proceso independentista, razón por la cual se les ha ubicado en un lugar central en las exposiciones. Representan un testimonio físico del prócer, prueba del acontecimiento clímax de esta historia, aquella batalla donde se forjó el destino de la patria. En un segundo orden se ubican los proyectiles, vestigios de estos combates como las balas de cañón o de pistolas, arqueología histórica recuperada desde el campo de batalla.

En el orden de los objetos alegóricos, es decir, aquellos referentes simbólicos del proceso independentista, destacan en primer orden las condecoraciones a próceres y soldados como medallas, testimonio de los servicios prestados al Ejército y que reafirman la heroicidad de éstos (como la medalla de la Legión al Mérito). También hay estampillas, monedas y medallas conmemorativas, elaboradas en el contexto del centenario o bicentenario de la Independencia nacional. Las banderas y el escudo patrio son elementos alegóricos que reafirman la vocación nacionalista de la muestra: las tres banderas patrias (la de la Patria Vieja, de transición y la actual con todas sus variantes), la del Ejército de los Andes y la enseña para la liberación del Perú son elementos insoslayables en la exposición. Dentro de los elementos simbólicos que mitifican a personajes de la gesta independentista hay, por ejemplo, un cofre que contiene tierra del solar natal de José de 
San Martín en Yapeyu, Argentina, en el Museo de Maipú. En un rango menor están las esculturas como bustos o estatuas que representan a los próceres. Resulta interesante en esta categoría el juego dialógico realizado en la sala "La Idea de Libertad" del Museo Histórico Nacional donde se encuentran tres grandes símbolos de la liturgia patria: un fragmento del escudo republicano en piedra tallada, el piano de Ramón Carnicer (quien compuso la música al himno nacional) y la gran bandera patria presente en la Jura de la Independencia.

La categoría pictórica comprende cuadros, grabados o bocetos, elementos artísticos infaltables en las exhibiciones estudiadas, destacando grandes pintores del siglo XIX que retrataron las glorias nacionales. Encontramos pintores de batallas y hechos históricos como Pedro Subercaseaux, Giulio Nanetti, Nicolás Guzmán y Thomas Somerscales. En el retrato relevantes son personajes como José Gil de Castro, Virginia Burgueois, Albino Quevedo y Mariano Carrillo. Del conjunto de obras figura el retrato de prócer como elemento dominante (O’Higgins, Carrera, San Martín), junto a los cuadros de batallas (Chacabuco, Rancagua, Maipú) y sucesos históricos (Primera Junta de Gobierno, Cruce de los Andes, Escuadra Nacional, Abdicación de O’Higgins, etc.). El arte exhibido representa acciones heroicas y ejemplares que sirven como herramienta pedagógica para el visitante. Ciertamente, la dimensión pictórica es acaso una de las más interesantes respecto a la representación independentista por la información visual que otorga al espectador y porque ha aportado a la construcción de un imaginario nacional con imágenes arquetípicas. La pintura tiene entonces un doble valor: ser producida por personajes de renombre en la escena artística nacional y como representación histórica de las glorias nacionales que han nutrido el imaginario colectivo hasta el presente. El ejemplo más memorable, y que bien podría situarse como un prócer más desde la vereda artística, es el caso de José Gil de Castro, contemporáneo de los hechos, soldado y cartógrafo a favor de la gesta independentista, cuya prolífica obra se exhibe en el Museo Histórico Nacional. Aunque Gil de Castro había retratado a la elite monárquica, posteriormente se dedicó a "enaltecer a los gestores de la autonomía latinoamericana”3. Por tanto, el acontecimiento independentista se encuentra aquí doblemente mediado, por el artista y por el museo.

Los documentos, finalmente, constituyen también elementos museológicos importantes, pues son testimonios directos del proceso cuya existencia confirman hitos y apreciaciones históricas que, a través de actas, bandos, informaciones o inventarios, reafirman la existencia de los protagonistas al estar redactados o firmados de su puño y letra. Las actas o declaraciones son formalizaciones de hechos históricos, así como los papeles administrativos y cartas. En segundo plano están los libros y la cartografía. Representativa de esta categoría es la fenomenal muestra documental del Museo del Carmen de Maipú, con impresos,

Gil de Castro “(...) tuvo como principal norte el afianzar y llenar de prestigio al movimiento independentista, no sólo chileno sino americano. Trabajó con decisión por inmortalizar a las figuras más relevantes de la hazaña política americana y, a través de ellas, reflejó los ideales de ese complejo periodo histórico. Sus modelos adquirieron un aura desconocida hasta entonces, traduciendo un altruismo y un heroísmo que se buscaba en la vida religiosa y ahora se encontraba en el campo de batalla. Así, pintando retratos, fue capaz de reafirmar su compromiso con los valores independentistas” (Maino, 2008, p. 21). 
Tabla 3. Recursos museográficos vinculados a la Independencia de Chile

\begin{tabular}{|c|c|c|c|c|c|}
\hline RECURSO & $\mathrm{MHN}^{*}$ & MHM & MCM & MMN & MRR \\
\hline Cédulas de identidad & - & - & - & - & - \\
\hline Paneles & - & - & - & - & - \\
\hline Audiovisuales & & - & $\bullet$ & & - \\
\hline Audioguías & $\bullet$ & & & & \\
\hline Aplicaciones móviles & & $\bullet$ & & & \\
\hline Montajes & & $\bullet$ & - & $\bullet$ & \\
\hline Dioramas & & $\bullet$ & & & $\bullet$ \\
\hline Maquetas & & $\bullet$ & & $\bullet$ & \\
\hline Interactivo/didáctico & $\bullet$ & $\bullet$ & $\bullet$ & $\bullet$ & \\
\hline Ficha de información & & & & - & \\
\hline
\end{tabular}

*MHN: Museo Histórico Nacional; MHM: Museo Histórico y Militar; MCM: Museo del Carmen de Maipú; MMN: Museo Marítimo Nacional; MRR: Museo Regional de Rancagua.

Fuente: Elaboración propia en base a trabajo de campo en los museos entre los meses de junio, julio y agosto de 2018.

manuscritos y planos sobre la Batalla de Maipú, la Expedición Libertadora y documentación personal de O’Higgins, San Martín y Carrera.

Complementaria a la exposición del objeto, la instalación de recursos educativos se convierte en una estrategia fundamental para la representación histórica que potencia a los objetos y enriquece el relato para el visitante. En la Tabla 3 se muestran distintos recursos usados por los museos para exponer las temáticas de la Independencia.

Las cédulas nombran a los objetos y los dotan de identidad y propiedad, mientras los paneles sirven para dar coherencia lógica a las salas articulando el relato independentista en una interpretación global y cronológica que ordena al conjunto de objetos en el espacio museal. Recursos audiovisuales, audioguías, aplicaciones móviles y fichas de información profundizan el relato histórico y ofrecen una descripción pormenorizada de objetos y vitrinas de una manera didáctica.

Otro conjunto de elementos representativos del relato independentista son aquellos fabricados para representar a un personaje o acontecimiento histórico como son los dioramas, montajes y maquetas. El diorama se convierte en un dispositivo museal fundamental para representar hitos históricos de la Independencia cuya temática versa casi exclusivamente sobre batallas. Situados en los espacios centrales y algunos de una factura colosal, dan contexto a los objetos que han sobrevivido al tiempo y se instalan como testimonios de verdad histórica. Destacan al respecto el gran diorama de la Batalla de Rancagua en el museo regional al que 
se le adicionan paneles informativos con los pormenores del enfrentamiento. En el Museo Histórico y Militar destaca también este tipo de recurso museográfico con dioramas alusivos a las batallas de Rancagua, Chacabuco y Maipú.

Los montajes, por su lado, corresponden a la construcción de ambientes, con o sin objetos de época, que recrean a sujetos o acontecimientos a partir de maniquíes debidamente caracterizados, acompañados de objetos, paneles, murales y estructuras. Destacan aquellos consagrados a los próceres, particularmente evidentes en el Museo Histórico y Militar, con montajes sobre José Miguel Carrera, Javiera Carrera, Manuel Rodríguez, Paula Jaraquemada, Bernardo O'Higgins, Manuel Blanco Encalada y Thomas Cochrane. Las maquetas corresponden a trabajos a escala, en su mayoría de embarcaciones de la primera escuadra nacional y los elementos interactivo/didácticos, finalmente, refuerzan el aprendizaje esperado de la sala museo haciéndolo apto para todas las edades. Son particularmente llamativas las pantallas interactivas de la Fundación Mustakis instaladas en el Museo del Carmen de Maipú, la "Máquina del Tiempo" del Museo Histórico Nacional o los recursos museográficos para personas no videntes en el Museo Marítimo Nacional, que exacerban la experiencia de representación nacionalista haciéndola asequible a distintos públicos.

\section{Imagen canónica}

Si bien cada museo tiene una personalidad propia que expresa una representación particular a partir de la selección y ordenamiento de los objetos en exhibición, se evidencia en este conjunto la convergencia hacia un relato global que es heroico, épico y, en algunos casos, hasta sacrosanto. Pese a los cambios museográficos en la forma de representar la colección, en el fondo subyace de forma casi imperturbable aquel sustrato prístino que busca reforzar la identidad nacional. De este modo la Independencia es el epicentro mismo del relato de la Historia de Chile, hito desde donde se interpreta el conjunto de la historia nacional. La musealización de la Independencia se presenta casi sin complejidades, como una gesta nacional de los "buenos" (patriotas) contra los "malos" (realistas), carente de problemáticas propias, donde claramente se identifican los bandos sin establecer matices en un periodo que es de por sí complejo, y donde las identidades nacionales y fidelidades no están del todo establecidas como ha indicado la historiografía reciente.

La selección de ciertos elementos para su exhibición museológica da cuenta de sujetos que se estiman relevantes en el proceso independentista y que por ello forman parte del panteón de héroes más o menos consensuado por el Estado, la academia y las Fuerzas Armadas, a saber: Bernardo O’Higgins, los hermanos Carrera (José Miguel, Luis y Javiera), Thomas Cochrane, José de San Martín, Manuel Rodríguez y, en menor medida, Ramón Freire, entre otros, son las figuras predominantes e iterativas. Como contraparte femenina de los héroes, son reconocidas Javiera Carrera (la "Madre de la Patria") y Paula Jaraquemada. El británico Thomas Cochrane, héroe naval, tiene su santuario en el Museo Marítimo Nacional, 


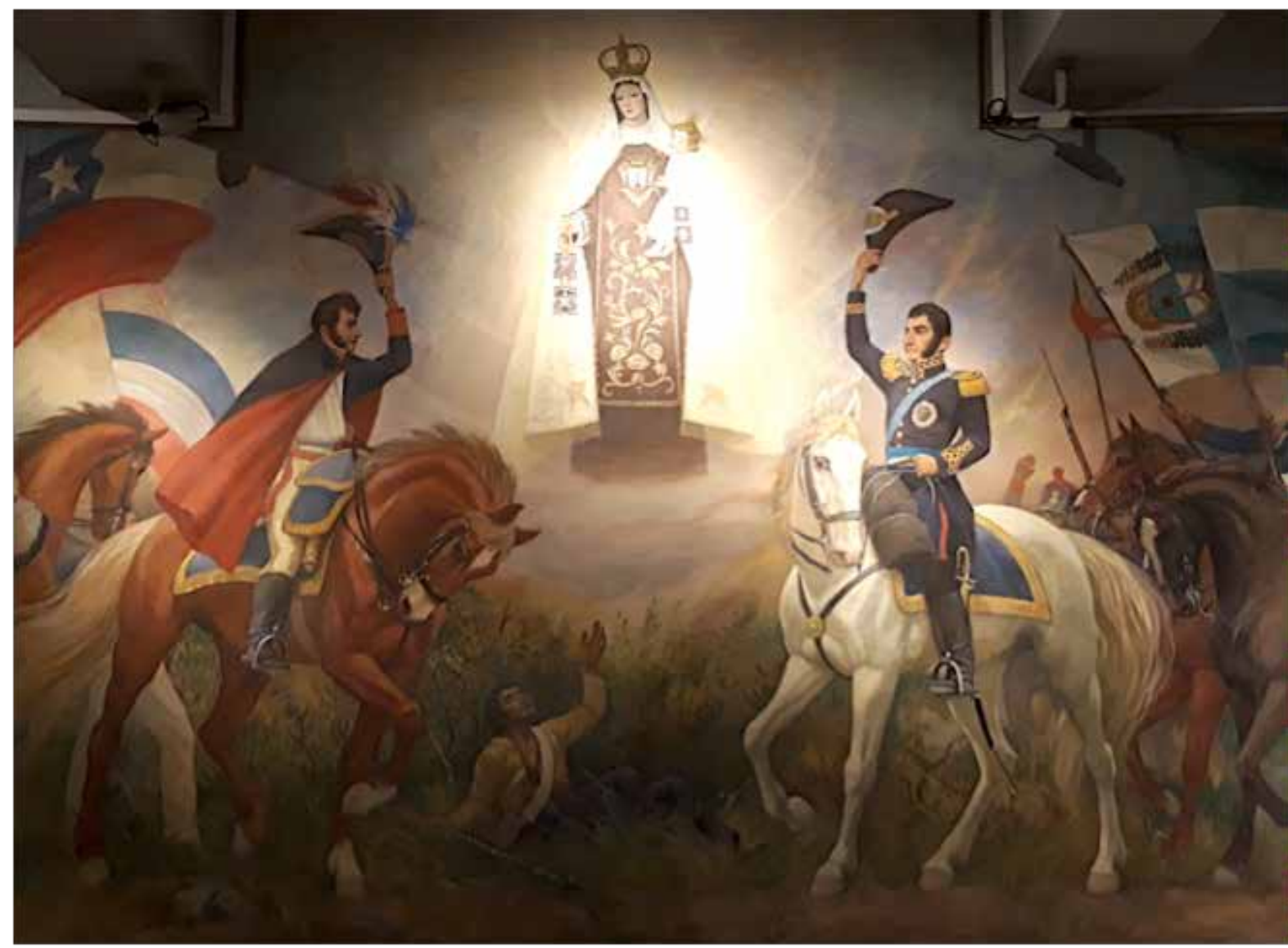

Fig. 2. Detalle del mural "Alegoría de la Batalla de Maipú” de Fray Pedro Subercaseaux en el Museo del Carmen de Maipú. Fotografía del autor, 2018.

con presencia también en los museos históricos de Santiago. Una figura relevante es la de José de San Martín, incuestionado prócer argentino, a quien se le reconoce su aporte a la Independencia nacional en todos los museos, pero es O`Higgins quien ocupa un sitial privilegiado como contraparte a su par trasandino (Fig. 2). La figura del caudillo chileno como "Padre de la Patria" es incuestionable, pues adquiere centralidad en toda exposición (el Museo Regional de Rancagua está dedicado en cierto modo del todo a su persona). Los objetos personales de los próceres, reliquias infaltables en los santuarios de la patria, reafirman su existencia y validan la narrativa museal mostrando una doble faceta: por un lado, la del héroe militar, con su indumentaria de batalla y armamento; y, por otro, su lado más íntimo, con objetos de uso cotidiano, que expresan la humanidad del prócer que se transmuta en divinidad tras el sacrificio de la batalla.

Las exposiciones exhiben también un triunfalismo evidente donde no cabe espacio para la derrota en el bando patriota; y cuando éstas ocurren, se presentan como la expresión del coraje y sacrificio de los próceres, un traspié en el camino hacia la victoria. La mayor parte de los dioramas ofrece esta mirada, donde los patriotas sobrepasan al ejército enemigo en 
la batalla. Así se resalta su heroísmo, como el caso de la Batalla de Rancagua, derrota que se interpreta como una hazaña memorable. Así, las exhibiciones presentan vidas ejemplares que desbordan austeridad, sacrificio y amor por la patria. Desde este punto de vista los museos -en especial aquellos militares- ostentan un enfoque pedagógico con elementos conductistas, es decir, que buscan la reproducción de ideas, valores y hábitos patrios en el visitante.

Hay que decir que todo héroe requiere un antagonista, y en este caso el villano de la película está personificado en la Corona española, el rey y sus delegados, el gobernador, el virrey, funcionarios civiles, religiosos y militares, representantes del antiguo régimen en América. En el siglo XIX, en primera instancia, las exhibiciones museales presentaron trofeos de guerra (como la Exposición del Coloniaje), realidad que ha cambiado hacia una exposición menos pasional y chovinista, lo cual obedece al reconocimiento posterior de España a las nuevas repúblicas americanas, decantado en un respeto mutuo tras la reconstrucción de las relaciones diplomáticas. Con excepción del Museo Histórico Nacional, casi no existen objetos de época que recuerden a los españoles en la época republicana (aunque para hacerles justicia sí tienen presencia en aquellas salas dedicadas al periodo colonial). La presencia hispana en la Independencia es más bien figurada a partir de la pintura (retratos y batallas) y los dioramas (como representantes del imperio hispano y soldados en combate), donde se les niega humanidad en tanto sujeto agresor e invasor.

\section{MIRADAS CRÍTICAS Y PROPUESTAS DISIDENTES}

El que los museos presenten en su exhibición permanente tópicos tradicionales no significa que no se hayan realizado esfuerzos que cuestionen el desarrollo de la nación como una construcción intencionada y que ofrezcan una performance crítica que tensione su relato. Ejemplos de ello son las exposiciones temporales Puro Chile. Paisaje y Territorio (2014) en el Centro Cultural La Moneda o El Bien Común (2017) del Museo Nacional de Bellas Artes. Estas muestras desplazan el impulso gravitacional de la nación del mito de los héroes incluyendo expresiones populares, alternativas y marginales que desafían el constructo oficial del imaginario patrio ${ }^{4}$. Ahora bien, el museo histórico, en contraste, tiene menos libertad para expresar una crítica sobre lo nacional que el mиseo artístico, debido a requerimientos de criterios de objetividad que forjan relatos más o menos consensuados y políticamente correctos. De ahí que las recientes exposiciones temporales del año 2018 vinculadas a la Independencia fuesen más discretas y continuasen reproduciendo la mitología patria relevando las virtudes de los próceres con títulos tan sugerentes como: Queremos, podemos y debemos ser libres (Galería de Cristal de la Biblioteca Nacional), O’Higgins a 240 años de su Nacimiento (Museo Regional

El Bien Común postulaba un divorcio de lo cronológico para "tensionar la idea de Nación desde una noción de comunidad que cuestiona el concepto de "bien común", colocando en escena la contribución que han hecho las artes visuales en la formación de un imaginario compartido" (Museo Nacional de Bellas Artes, 2017, p. 21). 
de Rancagua) y en especial aquellas del Museo Histórico y Militar: José Miguel Carrera, el Amanecer de la Patria; Pequeños Grandes Héroes, Marchando por la Historia; y Manuscritos de los albores de la Independencia.

Explorar relatos alternativos a los oficiales se convierte en una tarea fundamental para interrogar al museo histórico respecto a aquello que está exhibiendo y a su rol (y demanda ciudadana) como una institución de verdad. Para el propósito de este estudio, la historiografía se convierte en una disciplina de primer orden para resolver nudos narrativos y establecer interpretaciones alternativas respecto a la Independencia frente a un museo que ha continuado en lo fundamental replicando una imagen heroica y tradicional del periodo. Considerando que la función del museo no sea repetir lo que dice la academia o los currículos escolares, puede el conocimiento académico servir como un punto de apoyo para repensar su interpretación, pues aun cuando se cambia el foco de exhibición (hacia una exposición estructuralista o de las ideas), aún pervive en el fondo un relato común que es transversal: el gran relato del museo como un santuario de la patria. Frente a ello, se presentan a continuación algunas miradas historiográficas que ayudan a cuestionar los supuestos del periodo y, luego, se indaga sobre un ejercicio inédito de interpretación crítica de la Independencia a través de la polémica exposición temporal Hijos de la Libertad. 200 años de Independencia. 1818-2018 del Museo Histórico Nacional.

\section{La Independencia revisitada}

Estos últimos años han sido fecundos en la reflexión sobre la Independencia chilena con la celebración de su bicentenario (18/09/10), las batallas de Chacabuco (12/02/2017) y Maipú (5/04/2018), la declaración, firma y jura de la Independencia (1/01, 2/02 y 12/02 de 2018, respectivamente), entre otros acontecimientos célebres. Por este motivo a nivel nacional se han desarrollado desde la academia seminarios y coloquios que buscan reflexionar sobre este proceso y establecer su proyección en la actualidad. Un aspecto de no menor importancia es la aparición mediática de historiadores y escritores que han puesto en tensión la narrativa de la Independencia desde las páginas de sus textos, la prensa o la pantalla de la televisión. Todo ello ha generado cierta reflexión crítica o al menos un cuestionamiento respecto al periodo y sus figuras que ha traspasado las cúpulas académicas llegando al ciudadano común ${ }^{5}$.

La historiografía, con larga tradición académica, constituye la disciplina que otorga el discurso autorizado al proceso independentista, relato que es confirmado en el museo a través de su patrimonio, de objetos auténticos que sirven de contexto. La historiografía, en tanto que disciplina científica, está sujeta a un cuestionamiento permanente del que la museografía parece no seguir el paso, considerando que desde aquella fuente de conocimiento provienen las interpretaciones más rigurosas respecto a estos temas.

5 Es el caso del libro superventas Historia secreta de Chile del escritor Jorge Baradit (2015). 
Si bien el Museo Histórico Nacional no ha estado ajeno a un cuestionamiento interno y sus distintas áreas han organizado talleres, charlas y actividades para problematizar la exhibición museográfica, el resto de los museos estudiados aquí parece no haber pasado por este proceso reflexivo. Si bien esta institución no debe necesariamente reproducir los pormenores de la discusión académica, podría al menos reflejar estas consideraciones como referencias que expresan criterios interpretativos aplicables al museo, como una voz autorizada que permite establecer certezas fundamentada en su rigor científico.

Pero antes de poner sobre la mesa estas nuevas miradas es necesario indagar qué tipo de interpretación historiográfica evoca el museo histórico en la actualidad.

Siguiendo a Jocelyn-Holt, el enfoque de la Independencia desde la historiografía ha tenido un largo recorrido sobre los hechos y su significado que ha redundado en la configuración de dos grandes escuelas: la escuela liberal y la escuela conservadora. La escuela liberal, entre cuyos exponentes figuran Diego Barros Arana, Benjamín Vicuña Mackenna, Guillermo Feliú Cruz y Sergio Villalobos, propone que la Independencia habría sido un quiebre continuo con el pasado hispano, debido a un proyecto liberal, a nuevas ideas y un ideario revolucionario, en fin, “(...) al conjunto de creencias e instituciones vinculadas al contractualismo, al constitucionalismo, a los derechos naturales, al equilibrio de poderes, al Estado docente, a la noción de ciudadanía, de soberanía popular y de nación” (Jocelyn-Holt, 2016, p. 384). Esta interpretación sería cuestionada a inicios del siglo XX por historiadores de corte conservador como Alberto Edwards, Francisco Encina, Mario Góngora y Gonzalo Vial, que -por el contrario- sostendrían que hubo una restauración de tipo hispana y autoritaria entre 1830 y 1860 , cuando el Estado chileno se consolida y adquiere su naturaleza paradigmática generada por Diego Portales, es decir, un Estado fuerte, centralizado, de carácter autoritario, garante del orden y la tranquilidad (Jocelyn-Holt, 2016). Pese a estas diferencias respecto a las implicancias del proceso, las interpretaciones tanto liberal como conservadora coinciden en representar a la Independencia como una gesta heroica, crisol del "alma nacional", manifestando con ello un esencialismo histórico en los orígenes republicanos de mano de sus forjadores.

Se han citado estas miradas historiográficas grosso modo con el objeto de introducir respecto de aquellos supuestos interpretativos y filosóficos de la Independencia y que repercuten directamente en el trasfondo narrativo del museo desde su formación en el siglo XIX. Según los antecedentes mostrados en acápites anteriores, la mirada actual que prevalecería en los museos estudiados en relación al relato independentista corresponde a una mixtura de ambas escuelas con preponderancia de la interpretación liberal, una mirada lineal, optimista y progresiva de la historia, que quiebra totalmente con el mundo hispano, donde el concepto de libertad en todas sus manifestaciones es fundamental (considerando el carácter polisémico que puede tener el término). Ello ha estructurado el relato y ordenamiento expositivo estableciendo las pautas, límites y censuras, es decir, lo decible e indecible dentro del museo, derivado de consensos académicos y políticos previamente establecidos.

Dicho esto, cabe además presentar miradas historiográficas recientes que otorgan 
ciertos matices a lo que tradicionalmente se ha interpretado respecto al periodo en cuestión y que pueden ayudar a reformular el relato y ordenamiento del museo en la representación de la Independencia nacional.

Una primera mirada es el aporte de Cristian Guerrero, quien desentraña algunos mitos de la Independencia chilena en su libro 1817. De Mendoza a Chacabuco (2016) donde cuestiona la idea de la gesta independentista como un acto de unidad nacional, el que considera ha sido concebido más bien como un conflicto estereotipado y dividido de forma maniquea entre "patriotas" y "realistas", entre "buenos" y "malos":

"Como se trataba de construir una imagen nacional, el enemigo resultó ser un elemento al que no se prestó mayor atención. Sus posiciones políticas fueron simplemente descritas como continuistas del régimen monárquico, y sus adeptos como defensores de un orden que pretendía mantener operativo determinado sistema social, económico, cultural y político que marcaba diferencias y centraba los beneficios en uno de los polos de la relación hispano-americana" (Guerrero, 2016, p. 10).

El autor aborda estas dimensiones ignoradas por la triunfalista historiografía nacional estudiando también la situación desde la perspectiva del "enemigo", los realistas, de lo cual resultan convicciones ambiguas por parte de los soldados hispanos, criollos de nacimiento, que revelan las frágiles lealtades hacia la Corona española.

El historiador Gabriel Salazar, por su lado, critica la historia de la Independencia tal como se ha contado, una historia -indica- "saturada de estatuas y héroes que, en estricto rigor histórico y cívico, no han sido ni son ejemplares", pues en "ningún rincón de ella aparece el pueblo y/o la masa ciudadana como principal actor de su destino o el único héroe que debió y debe ser" (Salazar, 2015, p. 21), concluyendo que la memoria política de los chilenos debe ser revisada e intervenida. El nudo del problema deriva de la interpretación del periodo crucial de 1810-1837, donde se da una caracterización heroica de la Independencia chilena en detrimento de la posterior lucha por la democracia republicana. De ahí se desprende una serie de afirmaciones que identifican a Bernardo O'Higgins como un dictador sin méritos para ocupar el sitial en el que ha sido posicionado, reivindicando, por el contrario, al movimiento democrático impulsado por los pueblos de provincia y al general Ramón Freire como su caudillo (Salazar, 2015).

Haciendo eco del llamado de Salazar, Leonardo León en Ni patriotas ni realistas. El bajo pueblo durante la Independencia de Chile, 1810-1822 (2011), aborda este periodo desde la óptica de los grupos subalternos y su relación con las elites. Considerando su origen diverso y popular, los soldados poseían poca fidelidad respecto a sus superiores, lo que se expresó en la recluta forzada y la deserción de tropas. Según León, la guerra de independencia tenía un aspecto más de guerra civil que de liberación nacional, donde todo aquel que se opusiera al gobierno republicano sería castigado con exilio o muerte. La conciencia patriota y el espíritu revolucionario estaban encarnados más bien en la elite que en el pueblo propiamente tal, así que aquélla asumió dicho rol de forma excluyente y no representativa. Los grupos subalter- 


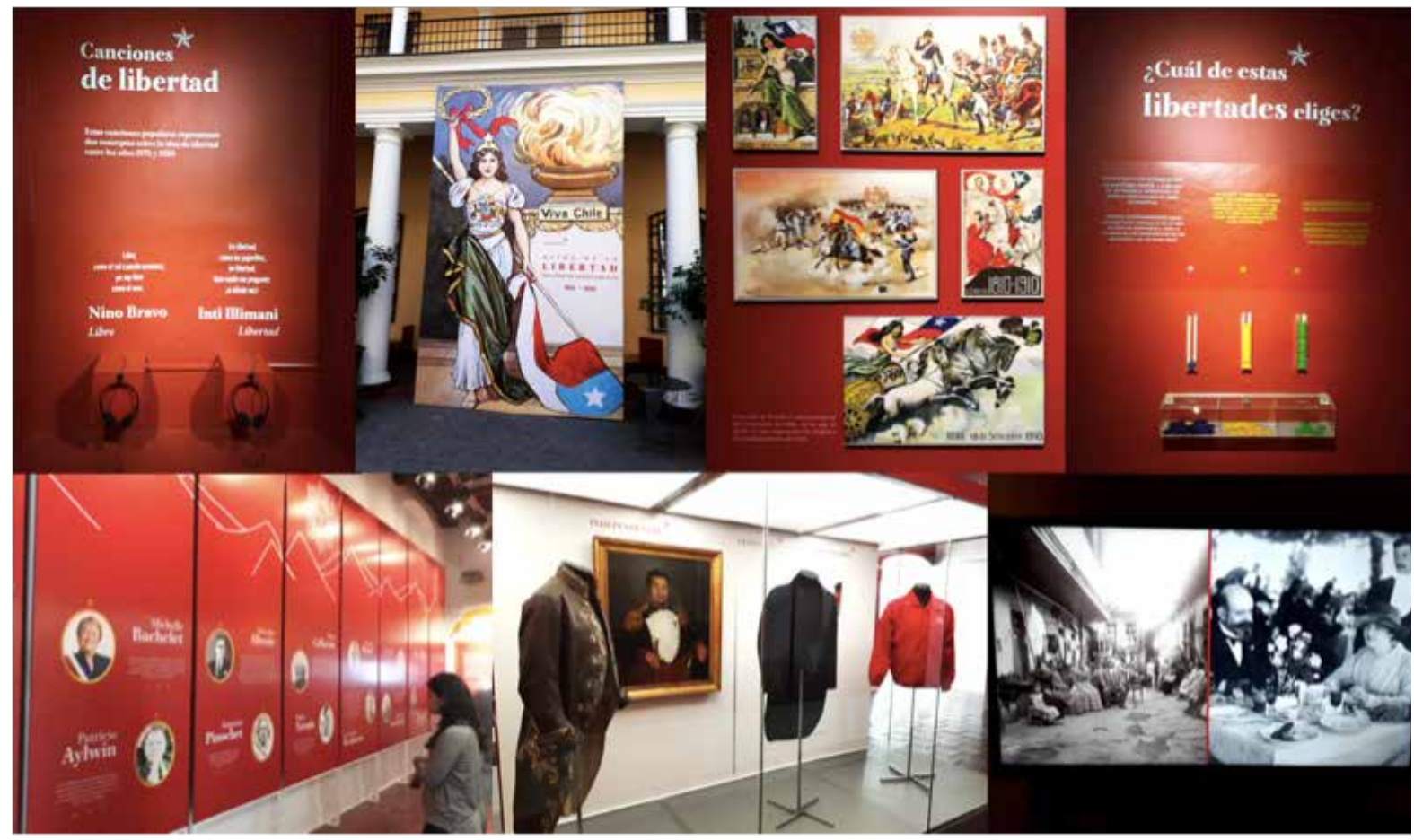

Fig. 3. Exposición temporal Hijos de la Libertad. 200 años de Independencia. 1818-2018 del Museo Histórico Nacional. Fotografías del autor, 2018.

nos (plebeyos, sirvientes, peones, inquilinos o indígenas) seguirían tan pobres y oprimidos como siempre; para ellos la Independencia no habría sido gloriosa ni épica.

En síntesis, estas miradas diversas, críticas y novedosas expresan interpretaciones que pueden contribuir a una mejor comprensión del proceso independentista en el museo. De una museología que logre representar las complejidades intrínsecas del periodo e integre la mirada hispano-realista y la realidad de los grupos subalternos, considerando la gestación de una conciencia nacional, desde donde emergen identidades diversas y resistencias a las compulsiones elitarias. También, es necesario descentralizar el acontecimiento, visto como una hazaña netamente capitalina para reconocer el aporte de las provincias, que levantaron proyectos y caudillos propios. Con ello el relato y la exposición museográfica se puede enriquecer enormemente al expresar la diversidad de interpretaciones del periodo.

\section{Hijos de la Libertad}

El 2018 se recordará en Chile como un año complejo para los museos, de batallas por la memoria y la historia reciente que han puesto al espacio museal en primera plana en el debate nacional. Esto demuestra su importancia y vigencia como institución representativa de temas aún no zanjados en la historia nacional. Hijos de la Libertad. 200 años de Independencia. 1818-2018 (inaugurada en abril de 2018 y clausurada ese mes) se recordará como una 
exposición temporal que suscitó una gran discusión en medios de comunicación y redes sociales sobre la inclusión de una imagen y cita del general Augusto Pinochet en la exhibición, controversia que culminó con la solicitud de renuncia de su director, Pablo Andrade, por la Ministra de las Culturas, las Artes y el Patrimonio, Alejandra Pérez, más tarde también destituida, entre otros motivos por este hecho. Más allá de la exposición mediática, poco se ha hablado sobre la propuesta museal de la exposición Hijos de la Libertad como una lectura y ejercicio crítico sobre el proceso independentista, frente a la imagen mítica y heroica tradicionalmente expuesta en el museo (Fig. 3). Por eso, yendo más allá sobre la pertinencia de la presencia del histórico dictador en la muestra, se busca analizar esta exhibición y determinar cómo se aparta del canon establecido respecto a la musealización de la Independencia.

Desde ya la exhibición se plantea como una mirada crítica en base al concepto de Libertad que es el leitmotiv que inicia el proceso independentista, abordado desde la larga duración histórica y su proyección en hitos conmemorativos, durante el centenario y bicentenario nacionales. El panel introductorio de esta muestra indica:

"Este momento nos permite realizar un balance sobre cómo la idea de LIBERTAD se concibió como una potencia de ideas que ha alimentado el proyecto país que hemos construido $y$ que deseamos seguir forjando. En este caso concreto, se trata de abordar una mirada patrimonial, que no busca agotarse en un gesto conmemorativo, sino por el contrario, ser parte de una mirada reflexiva, que instale una relectura y discusión de la idea de libertad más allá de la independencia, como un discurso que se "amplía" y "contrae", según ciertos ciclos históricos".

Bajo esta mirada, la muestra tensiona el relato de la Independencia y lo proyecta hasta la actualidad. El ejercicio es inédito en el museo, pues se aparta de la mirada tradicional e invita a la reflexión crítica de lo construido, imaginado y conmemorado en más de 200 años de historia republicana. Los "ciclos históricos" de la idea de libertad, con sus movimientos centrípetos y centrífugos, reconocen periodos complejos, en los que la dictadura militar conforma un hito de "contracción" de la libertad y donde el concepto es reinterpretado por el régimen". La conmemoración del centenario se aborda en tanto que crisis social y política que cuestiona el legado de la Independencia y se contrasta con la miseria de los sectores populares frente a la opulencia de los festejos oficiales. El Bicentenario, por su parte, aparece en el marco de la crisis del proyecto de modernidad y la instauración de la globalización, y las recientes oleadas migratorias a nivel mundial, así como la defensa de las libertades individuales y de los diversos estilos de vida.

La museografía de la exposición puso énfasis en los distintos discursos de libertad forjados durante la historia del país y el mundo, desde el general Bernardo O’Higgins hasta la

$6 \quad$ Es necesario mencionar que Pinochet se consideraba un segundo O’Higgins y los acontecimientos de 1973 una nueva Independencia, esta vez contra el "yugo marxista”. Desde su mirada y la de sus seguidores, el golpe de Estado era, en efecto, un acto de libertad del comunismo internacional, de la influencia de Cuba y la Unión Soviética en el marco de la Guerra Fría. 
ex Presidenta Michelle Bachelet, desde la niña judía Ana Frank hasta el cantante Nino Bravo, unificados todos bajo el concepto emancipatorio. Presentaba también la contextualización de la época de la Independencia, de su centenario y bicentenario, con objetos propios de cada época histórica (vestimenta y objetos) y del imaginario nacional representado a través de postales, medallas y cuadros, entre otros. Contó con recursos audiovisuales e interactivos que invitaban a ver, escuchar, descubrir y plasmar las ideas de libertad a través de ejercicios didácticos e interactivos que interpelaban al visitante. Un módulo invitaba al público a votar por nociones distintas de libertad: una libertad propia y autónoma, por la libre determinación, y la libertad de elegir mercancías y emprender con fin lucrativo, de manera de visualizar las ideas de los propios visitantes, también heterogéneas respecto al concepto.

La muestra invitaba en suma a reflexionar la Independencia nacional desde el concepto de libertad, desde nuestro propio presente y subjetividad, siguiendo los lineamientos del "museo de la idea”. Sin embargo, por la controversia aludida fue cancelada, paradojalmente, no por su propuesta crítica, sino por la inclusión de una imagen de Pinochet y la cita adjunta: "La gesta del 11 de septiembre incorporó a Chile en la heroica lucha contra la dictadura marxista de los pueblos amantes de su libertad". Esto fue interpretado de forma equívoca como un reconocimiento u "homenaje" a la dictadura militar, en vez de una complejización del concepto, como una herramienta discursiva que adquiere significados diversos acordes a los intereses que lo sustentan. Posteriormente se esperaba desarrollar dos exhibiciones temporales más bajo los conceptos de fraternidad e igualdad, respectivamente, completando así una trilogía conceptual sobre la Independencia. Exposiciones temporales como "Hijos de la Libertad" permiten estos juegos re-interpretativos y críticos que cuestionan a las exhibiciones permanentes heredadas del pasado y que son difíciles de reestructurar en el corto plazo. Se cree relevante entonces rescatar estas experiencias que, aunque efímeras y en este caso controversiales, constituyen intentos de deconstruir el relato oficial.

\section{CONCLUSIONES}

Esta investigación ha desarrollado un análisis integral respecto a la musealización de la Independencia chilena indicando los orígenes del museo y sus colecciones, resaltando los aspectos territoriales, académicos, políticos e ideológicos que han contribuido a la conformación de un relato que es fundamentalmente militar, heroico y nacionalista. Se han destacado dos etapas de construcción del museo histórico y las colecciones de la Independencia, una etapa formativa y efímera, donde se está comenzando con la recopilación de objetos y la construcción de un relato histórico. Ello desemboca en una segunda etapa iniciada con la instauración del Museo Histórico Nacional en 1911 y la consiguiente instalación de los museos históricos aquí estudiados, donde la Independencia actúa como eje vertebrador del discurso y ordena al museo en su conjunto. Es importante indicar el carácter dinámico de esta institución que ha experimentado reformulaciones en su trayectoria histórica superponiendo distintas formas de exhibición que van desde el museo tradicional hasta el museo de las ideas. 
Para establecer los fundamentos de la representación museal se han estudiado del mismo modo los objetos y recursos de las salas de exposición vinculadas a este proceso, confirmando así la reproducción de una imagen heroica y épica, propia de la memoria oficial sobre el proceso independentista. Se ha optado por abordar la exhibición en sí, de lo que se muestra y describe, por lo que no se considera el relato y ejercicios didácticos de visitas mediadas, donde pueden (y se dan) lecturas distintivas que interrogan al objeto apelando a la subjetividad de los visitantes, generando sinergias interpretativas que invitan a la reflexión a través del diálogo.

En general, se ha reestructurado y modernizado la forma de exponer los objetos mas no el fondo argumental, es decir, el relato que los ordena y significa. Esto se explica por el peso gravitante de una mirada oficial, estatal y militar, que rige los discursos del museo histórico y que refuerza nuestra tesis del museo histórico como un santuario donde se le rinde culto a la patria y a sus próceres. Hasta cierto punto el Museo Histórico Nacional ha desarrollado un ejercicio crítico con la instalación del museo de la idea y a través de intervenciones y exhibiciones temporales que invitan a pensar la historia de otro modo. En todo caso, la base historiográfica del relato del proceso independentista continúa estando desfasada respecto a los nuevos descubrimientos e interpretaciones. ¿Dónde están las mujeres, el soldado común, los hispanos, los mapuches, los bandidos, los héroes olvidados o las provincias? Estas interrogantes toman por asalto al museo y lo descubren como un lugar de representación elitista, representativo de la alta cultura y una tradición conservadora.

Por lo señalado es que se han explorado nuevas visiones historiográficas sobre la Independencia que contribuyen a reinterpretar críticamente estas miradas tradicionales, tanto liberales como conservadoras, que predominan con peso distintivo en cada museo. Del ejercicio de mirar la historiografía reciente aparecen nuevas interpretaciones desde donde emergen discursos subalternos que pueden ayudar a repensar el periodo. Desde la museografía, las exposiciones temporales e intervenciones pueden marcar la diferencia, es por eso que la exposición Hijos de la Libertad, pese a la controversia suscitada, se lee como una muestra que rompe con los esquemas tradicionales del museo revisando su conmemoración y significado histórico a partir del concepto de libertad. Con ello se puede resignificar y reestructurar el museo de acuerdo a los requerimientos de la nueva museología, con vocación social y carácter interdisciplinario, opuesto al modelo clásico centrado en las colecciones, hacia la construcción de un museo integral y reflexivo que interpele al pasado para construir el futuro. 


\section{REFERENCIAS}

Alegría, L., y Paz, G. (2007). Patrimonio y modernización en Chile (1910): La Exposición Histórica del Centenario. Atenea, 495, 69-81.

Alegría, L., y Meirovich, S. (2019). El museo y la historia militar: las colecciones del Museo Militar. En L. Alegría, Historia, museos y patrimonio. Discursos, representaciones y prácticas de un campo en construcción, Chile 1830-1930 (pp. 95-108). Ediciones del Servicio Nacional del Patrimonio Cultural.

Alvarado, I., Martínez, J., y Mellado, L. (2011). El Museo Histórico Nacional, su evolución y proyección. Revista Museos, 30, 35-41.

Baradit, J. (2015). Historia secreta de Chile. Editorial Sudamericana.

Anderson, B. (2013). Comunidades imaginadas. Reflexiones sobre el origen y la difusión del nacionalismo. FCE, México.

Campos, E., y Rodríguez, H. (1982). Museo Histórico Nacional. Dibam.

Cari, C. (2012). Museo de las Fuerzas Armadas y de Carabineros de Chile: diagnóstico de su gestión cultural. Tesis para optar al Grado de Magíster en Gestión Cultural, Facultad de Artes de la Universidad de Chile.

Castilla, A. (2010). La memoria como construcción política. En A. Castilla (Ed.), El museo en escena. Política y cultura en América Latina (pp. 15-36). Paidós/ Fundación Typa.

Castillo, O. (2007). El museo Naval y Marítimo de Chile. Revismar, 3, 274-279.

Gómez, J., e Infante, V. (2012). Blancos gordos con armas: Militarización de la Historia en las Museografías Nacionales. Ponencia presentada en el Simposio Internacional de Museología "Nuevas Prácticas, Nuevas Audiencias" en el Centro Cultural Gabriela Mistral, Santiago de Chile.

Guerrero, C. (2016). 1817. De Mendoza a Chacabuco. Corporación Conservación y Difusión del Patrimonio Histórico Militar. Universidad Bernardo O’Higgins.

Hernández, C. (2006). Chile a fines del siglo XIX: exposiciones, museos y la construcción del arte nacional. En B. González y A. Jens (Eds.), Galerías del progreso (pp. 261-290). Beatriz Bitervo Editora.

Hobsbawm, E., y Ranger, T. (Eds.) (2002). La invención de la tradición. Crítica.

Jocelyn-Holt, A. (2016). La Independencia de Chile. Tradición, modernización y mito. De Bolsillo. León, L. (2011). Ni patriotas ni realistas. El bajo pueblo durante la Independencia de Chile, 18101822. Ediciones Dibam.

Maino, H. (2008). José Gil de Castro. El retratista de la Independencia. Origo Ediciones. Museo Nacional de Bellas Artes (2017). El Bien Común. Colección MNBA 2017-2018. http://www. mnba.cl/617/articles-80694_archivo_01.pdf

Museo del Carmen de Maipú (2018). Museografía. http://museodelcarmen.cl/museografi/ Museo Regional de Rancagua (2018). Historia. http://www.museorancagua.cl/sitio/Secciones/ Quienes-somos/Historia/ 
Museo Histórico Nacional (2018). Historia. http://www.museohistoriconacional.cl/sitio/Secciones/Quienes-somos/Historia/

---- (2018b). Sala Idea de la Libertad. http://www.museohistoriconacional.cl/sitio/Contenido/ Institucional/30080:Sala-Idea-de-Libertad

Norambuena, C. (2002-2003). Imagen de América Latina en la Exposición Universal de París de 1889. Dimensión histórica de Chile, 17-18, 87-121.

Salazar, G. (2015). Construcción de Estado en Chile (1800-1837). Democracia de los "pueblos" Militarismo ciudadano. Golpismo oligárquico. Editorial Sudamericana.

Schell, P. (2003). Desenterrando el pasado con el futuro en mente. Exhibiciones y museos en Chile a finales del siglo XIX. Reino Unido: Universidad de Manchester. http://bbk.ac.uk/ ibamuseum/texts/Schello3sp.html

Seguel, R. (1999). Patrimonio cultural y sociedades de fin de siglo. Una mirada desde las nuevas tendencias que marcan los nuevos escenarios socioculturales. Revista Conserva, 3, 5-19.

Smith, L. (2006). Uses of Heritage. Routledge.

Urizar, G. (2012). Estado y Museos Nacionales en Chile durante el siglo XIX. Representación de una nación en construcción. Boletín Americanista, 65, 211-229.

Urzúa, C. (2019). Los monumentos y sitios del Ejército de los Andes: materialidad, representación y uso social de un patrimonio histórico-militar del valle de Aconcagua, Chile. Revista Sophia Austral, 23, 281-306.

Voionmaa, L. (2005). Escultura Pública. Del monumento conmemorativo a la escultura urbana, Santiago 1792-2004. Ocho Libros Editores. 